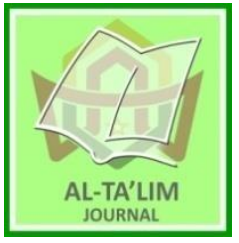

AL-TA'LIM JOURNAL, 28 (1), 2021, (1-8)

(Print ISSN 1410-7546 Online ISSN 2355-7893)

Available online at http://journal.tarbiyahiainib.ac.id/index.php/attalim

\title{
Sustainable Development: Learning the Quran Using the Tartil Method
}

Received: 04 $4^{\text {th }}$ December 2020 Revised: 06 ${ }^{\text {th }}$ February 2021; Accepted: $28^{\text {th }}$ February 2021

Permalink/DOI: https://doi.org/10.15548/jt.v28i1.673

\section{Syafrimen Syafril \\ Universitas Islam Negeri Raden Intan Lampung, Indonesia \\ E-mail: syafrimen@radenintan.ac.id}

\section{Nova Erlina Yaumas}

Universitas Islam Negeri Raden Intan Lampung, Indonesia

E-mail: novaerlina@radenintan.ac.id

\section{Engkizar}

Universitas Negeri Padang, Indonesia E-mail: engkizar@fis.unp.ac.id

\begin{abstract}
This study aims to investigating the effectiveness of using the tartil method in improving students' ability to read the Quran in elementary schools. This study uses a quantitative method with an experimental approach (true experimental pretest-posttest control group design). Data were taken from sixtysix students by means of pre-test and post-test of reading the Quran skills. All students involved are samples of the population which are used as research objects. The research data were then analyzed using descriptive statistics using the Statistical Package for Social Sciences (SPSS Windows 22.0). Overall, the results of the study indicate that the use of the tartil method in learning the Quran is very effective because it can improve students' abilities in reading the Quran. Therefore, the tartil method can be used as an alternative in learning the Quran.
\end{abstract}

\author{
Azhar Jaafar \\ University College of Yayasan \\ Pahang, Malaysia \\ E-mail: azhar@ucyp.edu.my
}

\section{Zainul Arifin}

Universitas Islam Negeri Imam Bonjol

Padang, Indonesia

E-mail: zainularifin@uinib.ac.id

Keywords: Effectiveness; method tartil; student; learning; Quran.

How to Cite: Syafril, S., Yaumas, N., Engkizar, E., Jaafar, A., \& Arifin, Z. (2021). Sustainable Development: Learning the Quran Using the Tartil Method. Al-Ta lim Journal, 1(1), 1-9. doi:https://doi.org/10.15548/jt.v28i1.673

\section{INTRODUCTION}

The Quran is the Muslim scriptures which Allah Subhanahu Wa Ta'ala (Glory to Him, the Exalted) revealed to Prophet Muhammad Sallallahu 'alaihi wa sallam (Peace be upon Him) as a miracle and a mercy to the universe, and life guidance, which governs the whole aspects of life. People who are always guided by the Quran always live amid an environment which is peaceful, fair, and full of compassion; maintain the meaning of comradeship; and never brag about anything (Shihab, 2007 \& 2013). The Quran brings blessings to the human life (Makhdlori \& Utami, 2007). It is the task of every Muslim to learn and ponder it (Mujab, 2014; Ishak et al. 2017). It is important for Muslims to read the Quran carefully (Hashim, 2015; Syafril \& Yaumas, 2017; Sai, 2018). This is stated in the Quran, i.s. surah al Isra' verse 9, which reads: Indeed, 
this Qur'an guides to that which is most suitable and gives good tidings to the believers who do righteous deeds that they will have a great reward.

Studies show that the use of an instructional technique and selection of a method by teachers are among the keys to successful implementation of instructional processes conducted by teachers (Noh, 2011; Abdullah, 2014; Engkizar et al. 2018; Yusnita et al. 2018). Other studies have also proved that there is a correlation between the instructional process conducted by the teacher and students' learning outcomes, in which interesting learning activities, the teacher's attitudes towards students, and the teacher's creativity in terms of classroom management can provide their own stimulus to the instructional process (Seymour, 2004; Yusof et al. 2011). This implies that a conducive situation and open-mindedness about the use of methods in the Quran instruction will make the instructional process more meaningful (Mssraty \& Faryadi, 2012; Asyafah, 2014).

The tartil method is one of the methods developed by Gazali in early 1993 to help students learn to read and write the Quran faster and more easily. The development of this method is intended to be an alternative to the phenomenon of the Quran instruction that tends to be monotonous, less creative, and less innovative. Conversely, the use of a method actively and creatively can arouse students' interest in the instructional process (Gazhali, 2008).

Several studies have shown that there is a room for improvement in the various methods used by teachers in the current Quran instruction, including in terms of the length of time spent to study the Quran and the acceptance of students of the method used (Strik, et al. 2007). Several methods have been used to identify students' mistakes in reciting the Quran. In the Netherlands, students study using the so-called acoustic feature method, which is a method to detect errors automatically (Lee \& Glass, 2012). This method has a positive impact on improvements in the Quran reading instruction and manages to identify the mistakes more comprehensively. Moreover, there is also a method that is based on comparisons using dynamic programming algorithms, i.e. this method is used by comparing between the correct pronunciation and the pronunciation under evaluation (Ariani, 2017). These studies indicate that numerous methods have been used to detect mistakes and the Quran reading instructional process (Arief, 2018; Khudori et al. 2019).

On average, students' abilities to read and write the Quran are poor (Purwanto, 1999; Fauziah, 2014; Atabik, 2014). Those studies were confirmed by another study which found that of the 230 students studied, $85 \%$ of them had poor Quran reading abilities and $15 \%$ of them could read the Quran well and correctly. The same condition also occurred in Raden Intan, Lampung, Indonesia, the researchers and some lecturers assigned as examiners in the Practicum Test of Worship Practices found that many students could not read the Quran well and correctly. What makes matters worse is that these students were supposed to be able to read the Quran well and correctly as once they graduated, they would be a graduate who is supposed to live according to the teachings of Islam. Therefore, this study tried to examine the effectiveness of the use of a method in the Quran instruction, namely the tartil method.

\section{METHOD}

This study used a quantitative method (true experiment pretest-posttest control group design) involving 66 students with poor Quran reading abilities. They were selected using the method of random assignment and grouped into two different groups (33 students in the experimental group and 33 students in the control group). To determine the effectiveness of the Quran instruction, data were collected by conducting the Quran reading test and, then, the data obtained were analyzed using descriptive statistics with the assistance of software Statistical Package for Social Science (SPSS) for Windows 22.0 (Creswell, 2007; Sugiyono, 2009). 


\section{RESULT AND DISCUSSION}

Results of the study showed that the use of the tartil method in the Quran instruction was effective. Chart 1.1 below shows a comparison between the improvement in students' Quran reading abilities before and after the use of two different instructional methods between the experimental group and the control group.

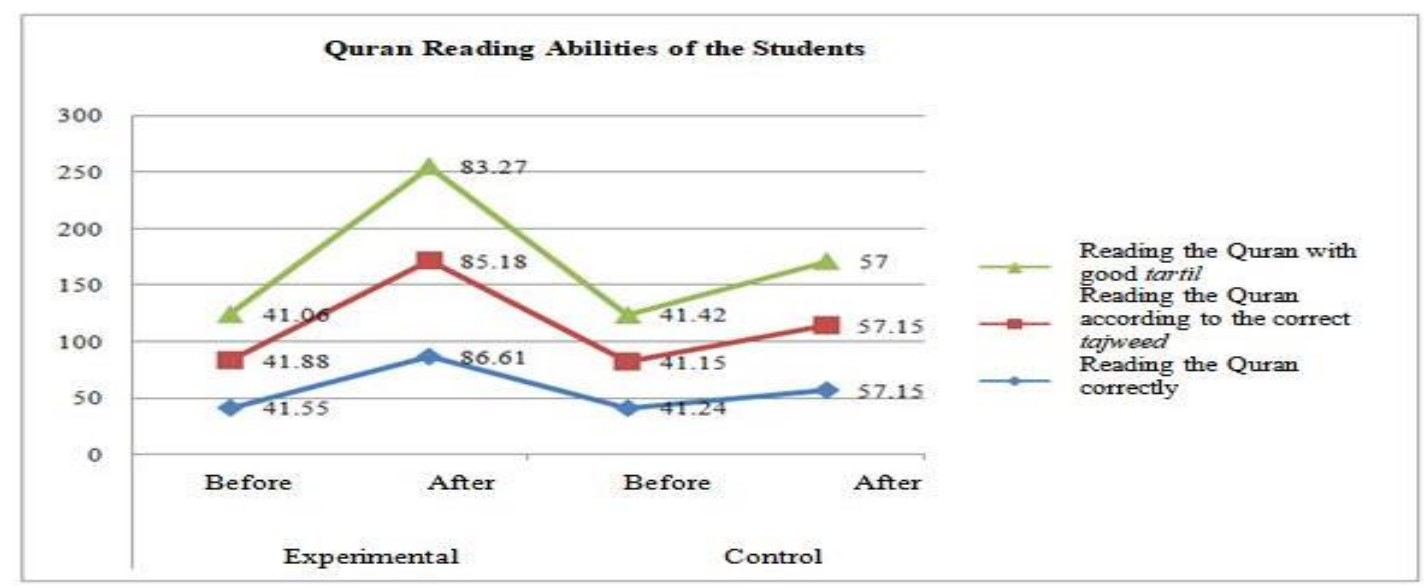

Chart 1. The Effectiveness of the Quran Instruction Using Two Different Methods

Chart 1. above shows improvements in students' Quran reading ability from very poor or unable to read the Quran at all to able to read the Quran well and correctly. Based on the analysis, the scores obtained by the experimental group are as follows: (i) reading the letters of the Quran correctly: prior to the use the tartil method $=41.55$, after the use the tartil method $=85.00$; (ii) reading the Quran according to the correct tajweed: prior to the use the tartil method $=41.88$, after the use the tartil method $=82.61$; (iii) reading the Quran with good tartil: prior to the use the tartil method $=41.06$, after the use the tartil method $=82.67$.

Furthermore, in relation to improvements in Quran reading abilities among students who learned using another method (the control group), results of this study showed that these students' Quran reading abilities also improved after the use of the method. However, the resulting increase remained less optimal, meaning that such an improvement remained unable to make students able to read the Quran well and correctly. The scores obtained by the control group are as follows: (i) reading the letters of the Quran correctly: prior to studying $=41.24$, after studying $=57.15$; (ii) reading the Quran according to the correct tajweed: prior to studying $=41.15$, after studying $=57.15$; (iii) reading the Quran with good tartil: prior to studying $=41.42$, after studying $=57.00$. Such an increase, if viewed based on the assessment standards developed by Ghazali, is considered inadequate or poor. In other words, their Quran reading abilities have not yet increased to a higher level (i.e. simple or good).

To generate students and graduates in the face of modern challenges, one of the challenges and things Muslims lag behind in terms of education are the use of teaching methods and curriculums (Hashim, 2005; Lubis \& Wekke, 2009; Niyozov \& Memon, 2011). There are many criticisms of teaching and learning methods in Islamic education (including the Quran reading and writing instruction). In Indonesia, stagnation and failures to respond to the needs, developments, and current challenges faced by students are evident (Agusti et al. 2018). The development of appropriate teaching and learning methods can help solve one of the problems and failures in the current instruction. Indeed, the use of effective methods and techniques by teachers should be the focus and get priority in the instructional process.

There are various methods to learn the Quran because learning to read the Quran does not mean knowing the letters and punctuation it contains only, but also getting 
to know the various aspects related to it (Ulum, 2007; Thoha, 2004). The Quran instruction using any method will certainly be accompanied by various forms of application that facilitate and create a pleasant interaction between students and teachers in the course of the instructional process (Abro et al. 2012; Khairul \& Haramain, 2018; Solihati, 2018; Halim \& Azizah, 2018; Hariandi, 2019).

The tartil method facilitates the instructional process through seven systematically designed steps. Of these seven steps, six steps aim to help students read the Quran well in a relatively short length of time and one step aims to strengthen the ways they read the Quran in accordance with the correct tajweed. These seven steps are; (i) teaching how to read individual Quran letters; (ii) teaching how to read Quran letters and verses with a "single line" punctuation, (iii) teaching how to read Quran verses with a "stop" punctuation, (iv) teaching how to read Quran verses with a "tasydid" punctuation, (v) teaching how to read Quran verses with a "double lines" punctuation, (vi) teaching how to read the Quran through murattal (i.e. reciting the Quran in a melodic tone of voice), and (vii) strengthen the ways to read the Quran using practical tajweed. The whole steps constitute an interconnected instructional process. In other words, the previous instructional process paves the way for successful mastery of knowledge in the next lesson.

This study shows that the use of the tartil method was effective for the Quran instruction. According to the researchers, it proves true that those seven steps facilitated the instructional process between the teacher and students and made the instructional process very fun because students were taught starting from the very simple things to the stage where they finally managed to read the Quran well and correctly. Therefore, it is assumed that the tartil method helps students to be able to read the Quran faster. This finding is consistent with that of the research by Arifin (2015), Hanafi et al. (2019), Hasna (2019)and Ruslandi (2019), which states that instructional process is not inseparable from the role of the teacher and the method used, and mutual assistance between students in the course of the instructional process. All of those processes described by Noor can actually be found in the tartil method.

As described earlier, to help students to be able to read the Quran well and correctly faster, the tartil method helps students using practical tajweed. As students learn this practical tajweed, they actually have been able to read the Quran well and correctly, but they have not understood why they read the Quran that way. This is because the previous learning materials do not discuss tajweed. However, they already have been taught how to read the Quran correctly in accordance with the rules of the correct tajweed, although they have not been taught the grounds why they read it that way. Based on the experience of the researchers themselves and the teachers who taught using this tartil method, such an instructional process is more effective than teaching tajweed in a theoretical manner when students have no previous experience at al reading the Quran well and correctly. In educational psychology, such a condition is referred to as learning by experience, aka inquiry learning. Students have passed this experience before, but they have not been told the term for the experience they went through. The researchers also consider this to contribute to the effectiveness of the tartil method in the Quran instruction. These findings turn out to be consistent, that tajweed helps improve the ways people who study it read the Quran. This is corroborated by Gazhali (2008) that tajweed instruction affects the abilities of students to read the Quran with goodtartil. Afterwards, students can learn to read the Quran through repeated exercises under teacher supervision. For example, the teacher demonstrates to students and get them listen to how to read the Quran well and correctly, guide them to identify reading mistakes and help them correct those mistakes, and guide them based on their own abilities.

It is this method which is actually applied in the process of learning the Quran using the tartil method. Previous studies 
also found that there were four things that helped students to be able to read the Quran faster using this tartil method, namely: (i) the method was very fun, simple, and practical; (ii) materials were presented briefly and arranged systematically; (iii) the materials were easy to remember because of the use of particular colorsin each material studied; and (iv) students were taught how to read the Quran well and correctly using the art of murattal. This findings are confirmed by the study conducted by that discovered that the Quran instruction using the tartil method helped students be able to read the Quranwell.

Gazhali (2008) classifies humans into four major groups, which in this study were associated with a teacher' openmindedness about developments in instructional methods in response to such developments for the betterment of their students. First, "teachers know and they know that they know". According to Ghazali, it is the right option for such individuals to choose being a teacher as their occupation. Second, "teachers do not know and they know that they do not know". Ghazali views this as teachers' wise personality. Such teachers are likely to be a good teacher because they always want to learn new things they do not know. Third, "teachers know but they do not know that they know". These teachers need to be reminded that they have potential that can be used to educate more effectively. These teachers usually need support from the environment to be able to use their potential maximally. Fourth, "teachers do not know but they do not know that they do not know". This category is for selfish teachers that always view themselves as a great person, do not want to accept others' views, and do not know their own shortcomings (Noor, 2017). In fact, to be a good educator, teachers need to be open-minded about changes that occur so quickly, including the latest findings related to the use of methods in the instructional process (Kasmar et al. 2019; Rahawarin et al. 2020; Putra et al. 2020).

\section{CONCLUSION AND RECOMMENDATION}

Based on the results of this study, it is evident that the tartil method can actually be used as an alternative method in learning the Quran for students. Indeed, there are various factors that contribute to the success of the learning process, such as teachers, the gentle attitude of students in the learning process, teacher motivation when teaching, and student interest in the learning process. learn. However, the teacher's sensitivity in choosing the method to be used will also determine the success of the learning process carried out. Referring to the results of this study, the author recommends Islamic religious education teachers, especially al-Quran teachers, to try to use the tartil method because it has been proven to improve students' reading skills of the Quran. Furthermore, to the next researchers to be able to continue further research related to the learning of the Quran, especially those related to the use of the method.

The highest thanks were conveyed to the late H. Ghazali who had devoted a part of his life to initiate this method in facilitating the learning of Quran in Indonesia. The author cannot extend the sharing of his generous teaching.

\section{REFERENCES}

Abdullah, M. (2014). Pengajian al-Quran dalam kalangan warga cacat penglihatan di Malaysia. Jurnal Al-Bayan, 8, 21-30.

Abro, B., Naqvi, A. ., \& Hussain, A. (2012). Qur'an recognition for the purpose of memorisation using Speech Recognition technique. In 2012 15th International Multitopic Conference (INMIC) (Pp. 3034).IEEE.10.1109/INMIC.2012.651144.

Agusti, F. A., Zafirah, A., Anwar, F., \& Syafril, S. (2018). The Implantation of Character Values toward Students through Congklak Game. Jurnal Penelitian Pendidikan, 35(2), 133-141. https://doi.org/https://doi.org/10.15294/ 
jpp.v35i2.13947.

Ariani, S. (2017). Program Bengkel Mengaji (Upaya Peningkatan Kemampuan Tahsin Al-Qur'an Mahasiswa PAI). Jurnal Mudarrisuna - Media Kajian Pendidikan Agama Islam, 5(1), 113-144. https://doi.org/10.22373/jm.v5i1.301

Arief, M. B. (2018). Pembelajaran Literasi untuk Meningkatkan Kemampuan Membaca Al Qur'an Hadits Siswa di Ma Nurul Qur'an Bendung Jogoroto Jombang. Progressa: Journal of Islamic Religious Instruction, 1(2), 29. https://doi.org/10.32616/pgr.v1i2.74

Arifin, Z. (2015). Tahfidzul Qur'an Program at SDIT Fajrul Islam Wiradesa Pekalongan Centre of Java Indonesia. Journal of Social Sciences and Humanities, 1(2), 92-97. http://www.aiscience.org/journal/jsshhttp ://creativecommons.org/licenses/by$\mathrm{nc} / 4.0 /$

Asyafah, A. (2014). The Method of Tadabur Qur'an: What Are the Student Views? International Education Studies, 7(6), 98-105.

https://doi.org/10.5539/ies.v7n6p98

Atabik, A. (2014). The Living Qur'an: PoTreT Budaya Tahfiz aL-Qur'an di nusanTara. $\quad 8(1), \quad 161-178$. https://doi.org/http://dx.doi.org/10.21043 /jupe.v8i1.1346.

Creswell, J. W. (2007). Research design: qualitative and quantitave approaches. Thousand Oaks: SAGE Publication.

Engkizar, E., Muliati, I., Rahman, R., \& ... (2018). The Importance of Integrating ICT into Islamic Study Teaching and Learning Process. Khalifa Journal of Islamic, $\quad 1(2), \quad 148-168$. http://kjie.ppj.unp.ac.id/index.php/kjie/ar ticle/view/9

Fauziah, S. (2014). Pembacaan Al-Qur'an Surat-Surat Pilihan Di Pondok Pesantren Putri Daar Al-Furqon Janggalan Kudus (Studi Living Qur'an). Jurnal Studi
Ilmu-Ilmu Al-Qur'an Dan Hadis, 15(1), 159. https://doi.org/10.14421/qh.2014.15108

Gazhali. (2008). Metode Tartil I Cara Cepat Membaca dan Menulis Al- Quran. CV. Najwa.

Halim, A. A. Al, \& Azizah, W. N. (2018). Upaya Peningkatan Kemampuan Membaca Al-Qur' an Melalui Pengenalan Huruf Hijaiyah Menggunakan Metode Qo'idah Baghdadiyah Ma'a Juz 'Amma (Turutan) Di Kelas 1A MI Ma'arif NU 01 Tritihkulon Tahun Pelajaran 2015/2016. Jurnal Tawadhu, 2(1), 490504.

Hanafi, Y., Murtadho, N., Ikhsan, M. A., Diyana, T. N., \& Sultoni, A. (2019). Student's and instructor's perception toward the effectiveness of E-BBQ enhances Al-Qur'an reading ability. International Journal of Instruction, 12(3), 51-68. https://doi.org/10.29333/iji.2019.1234a

Hariandi, A. (2019). Strategi Guru Dalam Meningkatkan Keterampilan Membaca Alquran Siswa Di SDIT Aulia Batanghari. Jurnal Gentala Pendidikan Dasar, 4(1), 10-21. https://doi.org/10.22437/gentala.v4i1.69 06

Hashim, A. (2015). Correlation between Strategy of Tahfiz Learning Styles and Students Performance in Al-Qur'an Memorization (Hifz).6(2S5), 85-92. https://doi.org/10.5901/mjss.2015.v6n2s $5 \mathrm{p} 85$

Hashim, R. (2005). Rethinking Islamic education in facing the challenges of the twenty-first century. American Journal of Islamic Social Sciences,22(4), 133.

Hasna, T. R. (2019). Implementation Of Bayani Method In Memorizing Al Qur'an At School Of Hafidz Qur'an Of Al-Islam Lamongan. Studia Religia: Jurnal Pemikiran Dan Pendidikan Islam,3(2), 277-284. 
Ishak, M., Syahfaruddin, \& Sit, M. (2017). Pelaksanaan Program Tilawah Alquran Dalam Meningkatkan Kemampuan Membaca Alqur' an Siswa Di Mas Al $\mathrm{Ma}$ ' Sum Stabat. Jurnal Edu Religia, 1(4), 602-618. jurnal.uinsu.ac.id/index.php/eduriligia/ar ticle/download/1166/915

Kasmar, I. F., Amnda, V., \& Maulida, A. (2019). The Concepts of Mudarris , Mu' allim , Murabbi , Mursyid, Muaddib in Islamic Education. Khalifa Journal of Islamic Education, 3(2), 107-125.

Khairul, K., \& Haramain, M. (2018). Aplikasi Digital Risalah Ilmu Tajwid dalam Meningkatkan Kemampuan Baca Alquran. KURIOSITAS: Media Komunikasi Sosial Dan Keagamaan, 11(2), 145-157. https://doi.org/10.35905/kur.v11i2.726

Khudori, A., Priyatna, M., \& Yasyakur, Mo. (2019). Penerapan Metode Ummi Dalam Meningkatkan Kemampuan Membaca Alquran Pada Siswa Di Kelas Iv Sd Kaifa Bogor.Prosa PAI: Prosiding Al Hidayah Pendidikan Agama Islam, 1(2B), 240-250. https://doi.org/http://dx.doi.org/10.30868 /ppai.v1i2B.502.

Lee, A., \& Glass, J. (2012). A comparisonbased approach to mispronunciation detection. In 2012 IEEE Spoken Language Technology Workshop (SLT) (Pp. 382-387). IEEE. 10.1109/SLT.2012.6424254.

Lubis, M. A., \& Wekke, I. S. (2009). Integrated Islamic Education in Brunei Darussalam: The Hopes and Challenges. Educare, 1(2).

https://doi.org/https://doi.org/10.2121/ed u-ijes.v1i2.198.

Makhdlori, M., \& Utami, F. (2007). Keajaiban membaca al-Qur'an: mengurai kemukjizatan fadhilah membaca al-Qur'an terhadap kesuksesan anda. Diva Press.

Mssraty, T., \& Faryadi, Q. (2012). Teaching the Qur'anic Recitation with Harakatt: A multimedia-based Interactive Learning Method. International Journal of Scientific \& Engineering Research,3(8), $1-4$.

Mujab, S. (2014). Evaluasi proses pembelajaran reading pada mata kuliah bahasa inggris II di Jurusan Tarbiyah Stain Kudus. 9(2), 357-384. https://doi.org/http://dx.doi.org/10.21043 /edukasia.v9i2.780

Niyozov, S., \& Memon, N. (2011). Islamic education and Islamization: Evolution of themes, continuities and new directions. Journal of Muslim Minority Affairs,31(1), 5-30. https://doi.org/https://doi.org/10.1080/13 602004.2011 .556886$.

Noh, M. A. bi C. (2011). Pelaksanaan Kelas Kemahiran al-Quran di Malaysia: Satu Analisis. Journal Os Islamic and Arabic Education, 3(1), 47-58.

Noor, A. Y. M. (2017). Challenges in the Teaching and Learning of Braille alQur'an at the Malaysian Association for the Blind (MAB). Islāmiyyāt,38(1).

Purwanto, S. (1999). Hubungan Antara Ingatan Jangka Pendek Dan Kecerdasan Dengan Kecepatan Menghafal Al-Quran. Psikologika: Jurnal Pemikiran Dan Penelitian Psikologi, 4(8), 70-83. https://doi.org/10.20885/psikologika.vol 4.iss8.art3

Putra, A. E., Rukun, K., Irfan, D., Engkizar, E., Wirdati, W., Munawir, K., Usmi, F., \& @ Ramli, A. J. (2020). Designing and Developing Artificial Intelligence Applications Troubleshooting Computers as Learning Aids. Asian Social Science and Humanities Research Journal (ASHREJ), 2(1), 3844. https://doi.org/10.37698/ashrej.v2i1.22

Rahawarin, Y., Engkizar, E., Hakim, R., Sari, W. W., Ramdani, N. S., Kasmar, I. F., Wulandari, S., Restari, Y. A., Mutathahirin, M., Amnda, V., \& Arifin, 
Z. (2020). Seven Motivations of Students Selecting Department of Islamic Teaching Education in Public University. Asian Social Science and Humanities Research Journal (ASHREJ), 2(1), 45-55. https://doi.org/10.37698/ashrej.v2i1.25

Ruslandi. (2019). Improving The Abilty Of Reading Qur'an Using The Iqra Method In Sdn 262 Panyileukan Bandung.EDUKASI: Jurnal Pendidikan Islam, 7(1), 54-61. https://doi.org/https://doi.org/10.5281/ed ukasi.v7i1.365

Sai, Y. (2018). Teaching Qur'an in Irish Muslim schools-curriculum, approaches,

Shihab, S. M. (2013). Alquran dan Maknanya. Lentera Hati.

Solihati, A. (2018). Peningkatan kemampuan membaca alquran melalui permainan huruf kartu hijaiyah. Jurnal Pelita PAUD,2((2)), 228-237. https://doi.org/https://doi.org/10.33222/p elitapaud.v2i2.242 .

Strik, H., Truong, K. P., Wet, F. D., \& Cucchiarini, C. (2007). Comparing classifiers for pronunciation error detection. In Eighth Annual Conference of the International Speech Communication Association.

Sugiyono. (2009). Metode Penelitian Kuantitatif, Kualitatif dan $R \quad \& \quad D$. Alfabeta.

Syafril, S., \& Yaumas, N. E. (2017). The implementation of Tartil Method in improving elementary school students' ability in reading al-Qur'an. Khalifa Journal of Islamic Educational, 1(1), 1- perspectives and implications. British Journal of Religious Education,40(2), 148-157.

https://doi.org/https://doi.org/10.1080/01 416200.2016.1269723.

Seymour-Jorn, C. (2004). Arabic language learning among Arab immigrants in Milwaukee, Wisconsin: A study of attitudes and motivations. Journal of Muslim Minority Affairs,24(1), 109-122. https://doi.org/https://doi.org/10.1080/13 60200042000212205.

Shihab, M. Q. (2007). Membumikan" alQuran: fungsi dan peran wahyu dalam kehidupan masyarakat. Mizan Pustaka.

14.

Thoha, C. (2004). Metodologi Pengajaran Agama. Pustaka Belajar.

Ulum, M. S. (2007). Menangkap Cahaya AlQur'an. UIN Malang Press.

Yusnita, Y., Eriyanti, F., Engkizar, E., Anwar, F., Putri, N. E., Arifin, Z., \& Syafril, S. (2018). The Effect of Professional Education and Training for Teachers (PLPG) in Improving Pedagogic Competence and Teacher Performance. Tadris: Jurnal Keguruan Dan Ilmu Tarbiyah, $\quad 3(2), \quad 123$. https://doi.org/10.24042/tadris.v3i2.2701

Yusof, R. J. R., Zainudddin, Roziati Yusoff, \& Mohd, M. Y. Z. (2011). Learning Methods and Problems of Qur' an Reciters (Malays and Africans). Centre of Quranic Research International Journal, Volume 1(No 1), 17-38. http://ejum.fsktm.um.edu.my/VolumeLis ting.aspx? JournalID $=22$ 